\title{
Pengembangan Strategi Pemasaran Ayam Barokah Melalui Digital Marketing
}

\author{
Hartanti $^{1}$, Rina Oktiyani ${ }^{2}$ \\ ${ }^{1,2}$ Universitas Bina Sarana Informatika \\ e-mail: ${ }^{1}$ hartanti.hti@bsi.ac.id, ${ }^{2}$ rina.roi@bsi.ac.id
}

\begin{abstract}
Abstrak - Perkembangan tekhnologi yang makin pesat mempengaruhi tren pemasaran saat ini, dimana mulai beralih ke pemasaran online atau digital marketing. Digital Marketing System memberikan kemudahan dalam berkomunikasi dan bertukar informasi, juga lebih mudah dalam menawarkan produk, serta jangkauan pemasarannya lebih luas dan efisiensi biaya pemasaran. Kemudahan inilah alasan penggunaan Digital Marketing System di Peternakan Ayam Barokah Karangwuni, Doplang,Teras, Boyolali. Metode penelitian yang digunakan adalah diskriptif kualitatif. Sumber data diperoleh dari hasil wawancara dengan para narasumber (informan) seperti peternak, pesaing, maupun konsumen, serta dari hasil observasi media online. Uji kevalidan data menggunakan triangulasi sumber. Teknik analisis data menggunakan analisis kualitatif yang terdiri dari reduksi data, penyajian data, dan penarikan kesimpulan. Hasil penelitan menunjukkan bahwa terdapat penurunan penjualan dikarenakan permintaan menurun ditambah dengan kondisi pandemi covid 19, Untuk mengantisipasi menurunnya penjualan secara konvensional, peternakan ayam Barokah melakukan pemasaran langsung kepada konsumen tanpa melalui distributor, merubah produk dalam bentuk ayam matang, dan dengan digital marketing system, seperti menggunakan media sosial berupa Facebook, WhatsApp maupun Instagram, yang kemudian dikembangkan dengan Website. Pengembangan strategi digital marketing tersebut melalui tahap segmentasi, targeting, dan positioning. Kemudian mengkombinasikan 3 unsur bauran pemasaran berupa harga, produk, dan tempat, untuk mendukung maka unsur kempat yaitu promosi sebagai inti dari strategi digital marketing. Pengembangan strategi digital marketing berisi informasi mengenai variasi produk, harga dan cara pemesanan, penjualan langsung maupun layanan pesan antar.
\end{abstract}

Kata Kunci: Strategi Marketing, Digital Marketing

Abstract - The rapid development of technology has influenced the current marketing trends, which have begun to shift to online marketing or digital marketing. Digital Marketing System provides convenience in communicating and exchanging information, also easier in offering products, as well as wider marketing reach and marketing cost efficiency. This ease is the reason for the use of Digital Marketing System in Barokah Karangwuni Chicken Farm, Doplang, Teras, Boyolali. The research method used is descriptive qualitative. Data sources were obtained from interviews with informants (informants) such as farmers, competitors, and consumers, as well as from online media observations. Data validity test uses source triangulation. Data analysis techniques using qualitative analysis consisting of data reduction, data presentation, and drawing conclusions. The results of the research show that there is a decrease in sales due to decreased demand coupled with the condition of the covid pandemic 19, To anticipate the conventional decline in sales, Barokah chicken farms do direct marketing to consumers without going through distributors, changing products in the form of cooked chicken, and with a digital marketing system, such as using social media in the form of Facebook, WhatsApp and Instagram, which are then developed with the Website. The development of digital marketing strategies is through the stages of segmentation, targeting, and positioning. Then combine the 3 elements of the marketing mix in the form of price, product, and place, to support the four elements, namely promotion as the core of digital marketing strategy. Development of digital marketing strategies containing information on product variations, prices and ways to order, direct sales and delivery services.

Keywords: Marketing Strategy, Digital Marketing

\section{PENDAHULUAN}

Jumlah pengguna internet di Indonesia, peringkat ke 6 di dunia sebagai pengguna internet. Menurut lembaga riset pasar e-Marketer, populasi netter Tanah Air mencapai 83,7 juta orang pada 2014. Pada 2017, e-Marketer memperkirakan netter
Indonesia bakal mencapai 112 juta orang, mengalahkan Jepang di peringkat ke-5 yang pertumbuhan jumlah pengguna internetnya lebih lamban. Proyeksi pengguna internet dunia dari tahun- ketahun, diprediksi akan terus meningkat. Pada tahun 2015 kemaren, diprediksi sudah mencapai 3 miliyard. Sementara pada tahun 2019 
mendatang, diperkirakan akan mencapai 3,6 miliyard pengguna internet. (Yusuf, 2014)

Jumlah pengguna internet yang semakin meningkat tentunya menjadi peluang bagi pemilik bisnis untuk bisa memanfaatkannya menjadi potensi penjualan. Adanya teknologi internet ini, manusia dapat melakukan banyak hal, seperti bersosialisasi ataupun komunikasi dengan manusia yang lain dalam jarak dekat maupun jauh, membaca buku, memperoleh berbagai informasi yang dibutuhkan, bahkan bisa berbelanja secara online. Sehingga dengan perubahan teknologi ini manusia dapat melakukan kegiatan seperti penjualan di dalam rumah maupun diluar rumah, karena komunikasi pemasaran yang awalnya hanya bisa dilakukan secara face to face (konvensional) sekarang juga dapat dilakukan secara screen to face (internet marketing).

Adanya internet maka promosi dapat dilakukan lebih efektif dan efisien, untuk itu berbagai kegiatan bisnis kecil sampai besar bisa memanfatkan perkembangan digital ini untuk menjalankan usahanya, termasuk dalam penjualan ayam barokah. Sistem marketing konvensional yang selama ini masih digunakan oleh sebagian pemilik bisnis, belum sepenuhnya memberikan pelayanan tercepat terhadap calon konsumen. Beberapa kelemahan yang terjadi saat transaksi menggunakan marketing konvensional, misalnya masih membutuhkan waktu, harus mempertemukan antara penjual dan pembeli, tentu bisa diatasi dengan pemasaran melalui internet atau digital marketing.

Menurut (Coviello et al., 2001) Digital Marketing adalah penggunaan internet dan penggunaan teknologi interaktif lain untuk membuat dan menghubungkan dialog antara perusahaan dan konsumen yang telah terindentifikasi. Mereka juga berpendapat bahwa e-marketing merupakan bagian dari e-commerce.

Menurut (Sanjaya \& Tarigan, 2009) digital marketing termasuk branding yang menggunakan berbagai media berbasis web seperti blog, website, email, adwords, ataupun jejaring sosial. Melalui marketing maka promosi lebih mudah, cepat, dan lebih murah, serta lebih mudah mengukur produk yang akan terjual.

Seiring dengan perkembangan era digital, akses internet semakin mudah dijangkau. Berbelanja online merupakan dampak dari pengunaan internet yang memungkinkan konsumen untuk menyebarkan positive word of mounth yang akan memberikan efek promosi ke konsumen lain . efek promosi berbelanja online membantu dalam pemasaran produk lebh luas dengan system digital marketing atau e-commerce (Aprilia, L. Cryrilla, 2018)

Sawicky dalam (Purwana, Dedi, Es, 2017) mengatakan digital marketing sebagai eksploitasi terhadap tekhnologi digital yang digunakan untuk menciptakan suatu saluran untuk mencapai tujuan perusahaan melalui pemenuhan kebutuhan konsumen yang lebih efektif. Sedangkan menurut Chaffey,
Chadwick, Johnston, Mayer dalam (Nadya, 2016) digital marketing merupakan pemasaran dengan menggunakan penerapan tekhnologi secara digital.

Media online akan menjadi platform komunikasi utama dalam pemasaran, dan off line store justru akan menjadi pelengkap, dikarenakan kemudahan, dan kemampuan untuk perbandingan dengan produk-produk lain dalam waktu singkat. Tingkat penyebaran yang tinggi, biaya yang lebih rendah dan efektifitas yang tinggi menjadi pertimbangan utama pemilihan digital marketing sebagai media pemasaran (Barus, 2016)

Berdasarkan hal ini maka peternakan ayam Barokah perlu melakukan system digital marketing, karena dengan system digital marketing, pada tahap awal peternakan Ayam Barokah dapat menentukan atau mengidentifikasi siapa pembeli produknya dan segmentasi pembeli potensialnya dari segi umur, lokasi, gender dan kebiasaan pembeli. Kemudian peternakan ayam tersebut dapat membuat konten yang relevan serta membubuhkan informasi produknya secara mendetail, misalnya jenis ayamnya, berat ayam, harga ayam dan kondisi ayam, berapa biaya angkutnya dan seterusnya.Setelah semua informasi sudah terpenuhi maka Ayam barokah dapat menentukan target penjualannya, meskipun dalam penjualan tidak semua goals diawal tapi bisa saja dengan adanya system digital marketing akan mendapatkan followers di media sosial atau mendapatkan review yang bagus sehingga produk Ayam barokah akan lebih cepat dikenal oleh banyak orang dan itu bagus dalam dunia bisnis.

Strategi digital marketing lebih memudahkan peternakan ayam Barokah dalam tahap melakukan proses review secara keseluruhan terhadap bisnisnya, seperti bagaimana pangsa pasarnya, apakah ada strategi yang harus diubah dan apakah ada pergeseran dalam target marketnya. Dengan digital marketing ini biaya pemasaran yang dikeluarkan tidak terlalu besar tapi bisa memasarkannya produk dalam skala lebih luas. Karena kegiatan jual belinya dapat melalui web maupun jejaring sosial jadi biaya yang dikeluarkan lebih murah, jangkauan pasarnya tanpa batas jarak dan waktu, dapat menjalin hubungan yang baik dengan pelanggan, pelanggan aktif, memberi feedback, dan segala bentuk informasi dapat tersebar luas secara cepat.

\section{METODE PENELITIAN}

Metode penelitian yang digunakan dalam penelitian ini adalah studi kasus pada peternakan ayam barokah Desa Karangwuni, Doplang, Teras, Boyolali dengan menggunakan analisis deskritif kualitatif. Penggunaan studi kasus sebagai metode penelitian dikarenakan penelitian ini bertujuan memberikan uraian secara lengkap dan mendalam 
mengenai strategi pemasaran yang dilakukan oleh peternakan ayam barokah.

Pendekatan yang digunakan dalam penelitian ini adalah pendekatan kualitatif yaitu pendekatan penelitian tanpa menggunakan angka statistik tetapi dengan pemaparan secara deskriptif yaitu berusaha mendeskripsikan suatu gejala, peristiwa, kejadian yang terjadi di saat sekarang, di mana peneliti berusaha memotret peristiwa dan kejadian yang terjadi menjadi focus perhatiannya untuk kemudian dijabarkan sebagaimana adanya.

Teknik pengumpulan data yang digunakan adalah observasi, wawancara, dan studi dokumentasi. Menurut (Sugiyono, 2016) menyatakan bahwa wawancara digunakan sebagai teknik pengumpulan data apabila peneliti ingin melakukan studi pendahuluan untuk menemukan masalah permasalahan yang harus diteliti, tetapi juga apabila ingin mengetahui hal-hal dari responden yang lebih mendalam.

Wawancara dilakukan dengan para narasumber (informan) baik pemilik peternakan ayam, pesaing, maupun konsumen, serta dari hasil observasi pada media online. Kemudian mengindentifikasi serta merumuskan masalah yang ada, dan data diuji menggunakan uji kevalidan data menggunakan triangulasi sumber

Teknik analisis data menggunakan analisis kualitatif yaitu proses secara sistematis untuk mengkaji dan mengumpulkan transkrip wawancara, catatan lapangan, dokumentasi, dan hal-hal lain untuk memperdalam pemahaman tentang fokus penelitian, baik dari hasil observasi, wawancara maupun dokumentasi catatan lapangan, dokumentasi, dan halhal lain untuk memperdalam pemahaman tentang fokus penelitian, baik dari hasil observasi, wawancara maupun dokumentasi untuk dijadikan sebuah temuan penelitian. Analisis data yang digunakan dalam penelitian ini adalah teknik analisis model interaktif yang dikembangkan oleh (Miles, M.B, Huberman, A.M, dan Saldana, 2014) yang terdiri dari reduksi data, penyajian data, dan penarikan kesimpulan.

\section{HASIL DAN PEMBAHASAN}

Usaha ternak ayam sebenarnya salah satu jenis usaha yang sangat potensial karena masa produksi yang relatif pendek, yaitu bisa dijual mulai dari 40-50 hari untuk ayam broiler, 60-70 hari untuk ayam joper, dan 70-75 hari ayam jantan, harga yang relatif murah, dan permintaan yang terus meningkat. Peternakan ayam Barokah di Doplang Teras Boyolali merupakan salah satu pelopor bisnis ayam ternak yang dirintis sejak tahun 2000. Masa kejayaan bisnis ternak ayam Barokah adalah saat permintaan ayam meningkat seiring dengan usaha warung makan dan restoran dengan menu ayam semakin digemari masyarakat mulai akhir tahun 2016-2018. Namun pada periode tahun 2018-2020 volume penjualan ayam dan pendapatan mengalami penurunan.

Tabel 1.

Volume Penjualan Ayam dan Pendapatan Peternakan

\begin{tabular}{|l|r|r|r|}
\hline \multirow{2}{*}{} & \multicolumn{3}{|c|}{ Periode Tahun } \\
\cline { 2 - 4 } & 2018 & 2019 & $2020^{*}$ \\
\hline Ayam (kg) & 9.049 & 6.963 & 2.372 \\
\hline $\begin{array}{l}\text { Pendapatan } \\
\text { kotor (Jutaan } \\
\text { rupiah) }\end{array}$ & 246,2 & 185,658 & 52,841 \\
\hline
\end{tabular}

Sumber: peternakan Ayam Barokah Periode 20182020

*Sampai Mei 2020

Tabel menunjukkan adanya trend penurunan jumlah penjualan ayam dari tahun 2018 hingga ke tahun 2020. Penjualan tahun 2019 menurun sebesar $23 \%$ dibanding 2018, sedangkan di awal 2020 ini penjualan baru mencapai $34 \%$ dari tahun sebelumnya. Hal ini berdampak pada penurunan pendapatan yang cukup signifikan. Apalagi saat pandemi Corona (Covid 19) yang melanda Indonesia mulai awal bulan Maret 2020, permintaan menurun tajam. Permintaan yang turun menyebabkan harga jual juga turun. Harga ayam hidup yang sebelumnya berada di angka Rp 19.500 per kg untuk ayam broiler, Rp 30.000 per kg untuk ayam jantan, dan Rp. 37.000 untuk joper. Pada awal April hinga pertengahan Mei 2020 harga ayam potong di tingkat peternak sempat mengalami titik terendah, merosot tajam hingga ke angka Rp. 17.000 per $\mathrm{kg}$ untuk ayam joper, Rp 10.000 per $\mathrm{kg}$ untuk ayam jantan, dan hingga Rp 7.000 - Rp 8.000 per kg untuk ayam boiler. Penurunan harga tersebut diiringi dengan merosotnya permintaan pasar sehingga peternak merugi, bahkan distributor tidak lagi mengambil sehingga stok ayam hidup di kandang pun menumpuk.

Hasil konfirmasi terhadap pemilik usaha peternakan ayam Barokah memang menyatakan terjadinya penurunan harga: tetapi untuk saat ini sudah lebih baik karena harga ayam beranjak naik. "Sekarang ini harga untuk ayam hidup dengan konsumen datang ke lokasi saat ini sebesar Rp. $35.000 / \mathrm{kg}$ untuk joper, Rp. $28.000 / \mathrm{kg}$ untuk jantan, dan Rp. 18.000 per kg untuk boiler. Dengan kisaran berat $0,8 \mathrm{~kg}-1 \mathrm{~kg}$,di lain tempat ada yang menjual ayam joper Rp. 37.000 per $\mathrm{kg}$, ayam jantan Rp. 30.000 per $\mathrm{kg}$, dan ayam boiler Rp. 19.000 per kg. Tetapi bagi saya, saat kondisi sekarang yang penting tidak rugi dan ada keuntungan sedikit. Harga ayam di tingkat pengecer mungkin bisa lebih tinggi. Saya kira harga dari peternakan saya cukup bersaing." (Wawancara tanggal 12 Juni 2020). Peternak lainnya menyatakan: 
"Kondisi permintaan ayam memang sedang menurun, sehingga harga ayam jatuh, saat ini kita rugi." (Wawancara tanggal 14 Juni 2020).

Sebagai usaha peternakan milenial, maka pemilik usaha peternakan ayam Barokah berusaha mencari solusi agar usahanya tidak semakin merugi. Berbagai bentuk strategi pemasaran dilakukan untuk menolong usahanya, mulai dari pemasaran langsung kepada konsumen tanpa melalui distributor, promosi penjualan, penjualan perorangan dalam bentuk ayam matang yang telah dimasak, hingga periklanan dan pemasaran interaktif di media online sebagai bagian dari digital marketing.

Strategi digital marketing merupakan jawaban atas menurunnya penjualan ayam secara konvensional di masa Pandemi Covid 19 saat ini. Melalui strategi ini ayam Barokah dapat mempromosikan atau memberikan informasi kepada pasar secara online dengan menggunakan berbagai media digital maupun jejaring sosial. Pengembangan strategi digital marketing ini dilaksanakan setelah ayam Barokah melakukan analisis segmentasi, targeting, dan positioning (STP).

Elemen penting dalam menyusun sebuah strategi pemasaran adalah terlebih dahulu menganalisis segmentasi, targeting, dan positioning dari produk yang hendak dipasarkan (Morissan, 2014). Analisis ini penting dalam menyusun sebuah strategi pemasaran agar perusahaan dapat lebih dahulu memposisikan segmen dan target pasar yang dituju dan posisi perusahaan terhadap peternak pesaing. Strategi STP ini untuk menilai apakah strategi digital marketing yang akan dilaksanakan sesuai dengan karakteristik usaha ternak ayam.

Hasil analisis STP menunjukkan bahwa usaha ternak ayam Barokah menggunakan segmentasi geografi dan psikografis. Segmentasi geografi yaitu segmen pasar adalah para distributor, pedagang, dan masyarakat konsumen yang berada di wilayah antara Boyolali, Kartasura Solo, dan sekitarnya. Segmen psikografis yaitu masyarakat yang aktif menggunakan internet dan suka berbelanja online melalui smartphone ataupun komputer (website). Target dari pemasaran usaha ternak ayam Barokah adalah masyarakat umum yang tidak terbatas pada segmen umur tertentu, atau kelas ekonomi tertentu karena produk ayam yang dijual bisa diterima di semua tingkatan pendapatan. Sedangkan positioning ayam Barokah adalah produsen ayam yang berkualitas, higienis, bobot yang sesuai, sehat dan aman untuk dikonsumsi.

Setelah melakukan analisis Segmentasi, Targeting, dan Positioning (STP), usaha ternak ayam Barokah kemudian menyusun bauran pemasaran untuk mendukung strategi digital marketing. Tiga unsur bauran pemasaran berupa harga, produk, dan tempat dikombinasikan untuk mendukung unsur promosi sebagai inti dari strategi digital marketing.
Tabel 2.

Bauran Produk dan Harga

\begin{tabular}{|c|c|c|c|}
\hline Jenis Ayam & $\begin{array}{l}\text { Variasi } \\
\text { Bobot } \\
\text { Produk } \\
\text { Ayam } \\
(\text { Kg) }\end{array}$ & $\begin{array}{l}\text { Harga } \\
\text { Pasaran } \\
\text { Umum } \\
\text { Ayam } \\
(\mathrm{kg})\end{array}$ & $\begin{array}{l}\text { Harga } \\
\text { Ayam } \\
\text { Barokah } \\
\text { (kg) }\end{array}$ \\
\hline \multirow[t]{2}{*}{ Ayam Joper } & $>2,0$ & $\begin{array}{l}\text { Rp. } \\
37.000\end{array}$ & $\begin{array}{l}\text { Rp. } \\
35.000\end{array}$ \\
\hline & $<2,0$ & $\begin{array}{l}\text { Rp. } \\
35.000\end{array}$ & $\begin{array}{l}\text { Rp. } \\
33.000\end{array}$ \\
\hline \multirow[t]{2}{*}{$\begin{array}{l}\text { Ayam } \\
\text { Pejantan }\end{array}$} & $>2,0$ & $\begin{array}{l}\text { Rp. } \\
30.000\end{array}$ & $\begin{array}{l}\text { Rp. } \\
28.000\end{array}$ \\
\hline & $<2,0$ & $\begin{array}{l}\text { Rp. } \\
28.000\end{array}$ & $\begin{array}{l}\text { Rp. } \\
26.000\end{array}$ \\
\hline \multirow[t]{2}{*}{$\begin{array}{l}\text { Ayam } \\
\text { Boiler }\end{array}$} & $>2,0$ & $\begin{array}{l}\text { Rp. } \\
19.000\end{array}$ & $\begin{array}{l}\text { Rp. } \\
18.000\end{array}$ \\
\hline & $<2,0$ & $\begin{array}{l}\text { Rp. } \\
17.000\end{array}$ & $\begin{array}{l}\text { Rp. } \\
16.000\end{array}$ \\
\hline Keterangan & \multicolumn{3}{|c|}{$\begin{array}{l}\text { Ayam Hidup, Harga sewaktu- } \\
\text { waktu berubah sesuai harga pasar }\end{array}$} \\
\hline
\end{tabular}

Sumber: Peternakan Ayam Barokah, 2020

Dari segi harga, usaha ternak ayam Barokah telah berusaha menyesuaikan harga dengan kondisi pasar. Hal ini agar tidak kalah dengan harga dari peternak pesaing. Ditinjau dari produk, agar lebih diterima oleh masyarakat maka produk yang dijual juga menyesuaikan dengan permintaan konsumen, mulai dari ayam hidup, ayam potong bersih, hingga ayam matang siap makan. Sedangkan ditinjau dari lokasi, keberadaan usaha ternak ayam Barokah adalah cukup strategis, mudah dijangkau oleh konsumen dan dekat dengan tempat wisata.

Hasil wawancara dengan pemilik peternakan ayam Barokah menyatakan: "Kandang kami cukup strategis, bisa diakses dengan mobil pickup maupun truck, dan dekat dengan lokasi wisata seperti waterboom cokro, pemandian atau wisata air umbul janti, wisata ponggok, dan pemancingan janti, serta wisata edukasi pengolahan limbah mendaji produk yang bisa bermanfaat untuk masyarakat, seperti pengolahan sampah plastik menjadi paping, bunga hiasan, tas, dompet. Dan sampah kertas bisa dibuat keranjang buah, lampu hiasan dsb, sedangkan untuk yg sampah alami diolah menjadi pupuk. Sehingga dengan kondisi yang strategis masyarakat maupun distributor dengan mudah dapat mencapai lokasi. Sedangkan untuk ayam matang siap makan, kita memasakknya di rumah, tidak di kandang, sehingga terjamin kebersihannya." (Wawancara tanggal 12 Juni 2020).

Setelah 3 unsur bauran pemasaran berhasil dikondisikan maka strategi digital marketing dapat dijalankan. Pengembangan strategi digital marketing ayam Barokah dilakukan melalui (1) periklanan online yang berisi informasi mengenai variasi produk, harga dan cara pemesanan; (2) penjualan langsung sebagai tindak lanjut pemasaran online yaitu 
konsumen datang ke kandang ataupun melalui layanan pesan antar. Jadi konsumen tidak perlu datang ke tempat penjual untuk melakukan transaksi. (3) penjualan pribadi yang dilakukan dengan pemaparan atau presentasi pada konsumen yang mewakili kelembagaan/organisasi, serta (4) pemasaran interaktif (tanya jawab) di media online Facebook, WhatsApp dan Instagram.

Strategi digital marketing ini dinilai lebih efesktif dan efesien karena sejalan dengan perkembangan jejaring sosial yang semakin mudah diakses oleh siapapaun.

1. Periklanan online

Usaha ternak ayam Barokah menggunakan berbagai macam bentuk iklan khususnya media iklan online (Facebook, WhatsApp, Instagram), agar masyarakat dapat mengetahui keberadaan ternak ayam serta jenis-jenis ayam yang dijual sehingga konsumen tertarik untuk membeli ayam. Usaha ternak ayam Barokah telah memanfaatkan WhatsApp dengan memasang foto di halaman stastus dan megirimkan foto tersebut ke orang-orang yang ada dikontak, dan dengan Facebook dengan memasukkan gambar atau foto barang yang akan dijual dan mengetag atau mengirim ke wall atau halaman depan temanteman dalam satu komunitasnya, maka iklan tersebut akan langsung tersebar dengan cepat. Anggota komunitas dengan membuka Facebook, iklan tersebut akan tampil dengan sendirinya, teman-teman dalam komunitas yang telah ditag atau dikirim tadi akan langsung dapat melihat pemasarannya.

Periklanan melalui Instagram merupakan media sosial yang aktif digunakan untuk menyebarkan informasi-informasi terbaru mengenai produk ayam baik ayam hidup maupun ayam olahan dengan berbagai macam jenis masakan. Instagram merupakan aplikasi pada smartphone yang digunakan untuk membagikan foto dan video. Foto dan video yang telah diunggah bisa disertakan dengan teks atau keterangan yang menggambarkan foto ataupun video tersebut. Instagram menjadi salah satu media sosial yang dapat dimanfaatkan sebagai media iklan dan berinteraksi dengan konsumen, sehingga konsumen dapat melihat jenis-jenis barang/jasa yang ditawarkan hingga promosi yang tengah berlangsung.

Melihat adanya perkembangan setelah menggunakan media social yang berupa Facebook, WhatsApp, Instagram maka Selanjutnya peneliti tertarik untuk lebih mengembangkan lagi dengan membuatkan website untuk memasang iklan online. Iklan di website usaha ternak ayam Barokah berisi mengenai jenis ayam, kondisi ayam, harga, jenis masakan, dan cara pemesanan. Hal tersebut mampu menjawab pertanyaan pasar dan meningkatkan kredibilitas perusahaan di mata pelanggan. jika dibandingkan dengan peternak pesaing, Usaha ternak ayam Barokah menjadi yang paling unggul dalam hal penyajian materi produk karena tampilan website yang menarik, lengkap, dan jelas.
Usaha ternak ayam Barokah menggunakan update status di Facebook untuk membuat iklan dan menjangkau seluruh grub yang diikuti serta Market Place. Fitur highlight pada Instagram untuk menjadikan konten yang ditampilkan dapat bertahan lama dan mudah diakses oleh Followers, karena fitur tersebut akan selalu Usaha ternak ayam Barokah menggunakan update status di Facebook untuk membuat iklan dan menjangkau seluruh grub yang diikuti serta Market Place. Fitur highlight pada Instagram untuk menjadikan konten yang ditampilkan dapat bertahan lama dan mudah diakses oleh Followers, karena fitur tersebut akan selalu menampilkan konten di halaman terdepan akun Instagram dan berada di posisi paling atas, berbeda dengan konten foto lainnya. Hal ini menjadi nilai utama bagi ayam Barokah dalam memberikan informasi mengeni produk ayamnya kepada calon konsumen.

2. Pemasaran langsung

Untuk mendukung pemasaran online, tentunya ayam Barokah memerlukan keberadaan kandang yang secara fisik berfungsi sebagai display untuk memajang produknya juga menjadi tempat penjualan produk secara langsung. Ayam yang dijual dibiarkan dalam kondisi hidup di kandang yang bersih dan luas. Bagi yang kesulitan dalam hal keterbatasan waktu bisa melakukan layanan pesan antar (delivery order).

Keberadaan kandang sebagai display dapat membangkitkan minat konsumen, sehingga konsumen merasakan kebutuhan yang mendesak untuk membeli produk yang dipromosikan. Keputusan pembelian seperti ini disebut sebagai pembelian seketika. Display yang menarik juga dapat menggugah rasa ingin tahu konsumen akan suatu produk, menggoda konsumen untuk mencoba suatu produk, bahkan menimbulkan keinginan untuk dapat memiliki produk yang dipromosikan. Suatu produk yang didukung oleh Display mempunyai posisi yang lebih kuat dalam mempengaruhi konsumen didalam memilih produk yang akan dibeli. Keberadaan kandang sebagai lokasi penjualan langsung juga menjadi media iklan dimana konsumen dapat memperoleh informasi yang berhubungan dengan produk secara langsung.

Pemasaran langsung yang diaplikasikan oleh ayam Barokah sesuai dengan bentuk direct marketing yang dikemukakan oleh (Kotler \& Armstrong, 2012) bahwa iklan online, pemasaran langsung, pemasaran teknologi digital baru, dan pemasaran online menunjukkan semakin mudahnya calon konsumen mendapatkan informasi. Semakin banyaknya kemudahan akses informasi antara ayam Barokah dengan pelanggan, maka akan tercipta rasa saling percaya, karena pelanggan akan lebih mudah mengetahui informasi terbaru yang ditawarkan ayam Barokah dan pelanggan juga lebih mudah untuk bertanya apabila ada hal-hal yang ingin diketahui. Oleh karena itu kemudahan akses komunikasi dan 
banyaknya saluran komunikasi yang digunakan akan memudahkan ayam Barokah dalam menawarkan ayamnya.

3. Promosi penjualan

Usaha ternak ayam Barokah menerapkan kegiatan promosi melalui pemberian diskon untuk menarik minat pelanggan. Promosi penjualan dengan pemberian diskon tentunya diinformasikan di media online sehingga seluruh masyarakat yang mengaksesnya bisa mengetahui program tersebut. Pemberian diskon tersebut disesuaikan dengan jumlah pembelian tetentu atau bertepatan dengan moment tertentu yang tujuannya untuk meningkatkan penjualan. Potongan harga yang diberikan berkisar antara 5\% hingga $10 \%$. Pelaksanaan promosi penjualan dengan memberikan potongan harga (diskon) dapat meningkatkan daya tarik pelanggan untuk membeli ayam. Program diskon rutin dilakukan setiap hari. Bertujuan untuk menaikkan animo konsumen dalam berbelanja ayam. Potongan harga lebih besar tentunya bagi distributor atau pelanggan dari kelembagaan yang membeli dalam jumlah besar

\section{Personal selling}

Penjualan pribadi (personal selling) dilakukan dengan cara presentasi merupakan strategi yang baik untuk memberikan informasi mengenai jenis-jenis produk olahan ayam maupun ayam hidup. Penjualan personal ini berfungsi agar konsumen dapat mengetahui lebih banyak lagi tentang ayam Barokah, sehingga apabila ada hal-hal yang tidak diketahui dapat ditanyakan langsung. Selain dengan bertatap muka, proses ini juga dapat dilakukan dengan mengirimkan email atau surat ke Usaha ternak ayam Barokah. Inilah salah satu strategi yang diterapkan ayam Barokah.

Kegiatan penjualan personal ayam Barokah adalah dengan presentasi dapat membuat pelanggan mengetahui lebih jelas keunggulan produk ayam yang dijual dibanding produk peternak lain, sehingga pelanggan lebih yakin karena terjalinnya komunikasi dua arah secara langsung. Hal ini sesuai dengan penjelasan menurut (Kotler \& Armstrong, 2012) bahwa komunikasi langsung tatap muka antara satu calon pembeli atau lebih dimana mereka memberikan umpan balik segera terhadap sumber pesan dalam bentuk presentasi. Dengan pengetahuan yang di dapat tersebut, akan membuat pelanggan tetap setia menjadi pelanggan yang loyal.

\section{Pemasaran interaktif}

Usaha ternak ayam Barokah melakukan pemasaran interaktif melalui beberapa media yaitu telepon, WA, serta memanfaatkan Messenger di Facebook dan Direct Messenger di Instagram. Facebook yang dimiliki oleh ayam Barokah memungkinkan konsumen untuk dapat memberikan komentar dan mengkonsumsi informasi dari update status. Instagram juga menjadi salah satu media sosial yang dimanfaatkan oleh ayam Barokah untuk menjalankan komunikasi pemasaran.
Ayam Barokah melalui Instagram juga mengunggah foto secara real time untuk memasarkan produknya. Usaha ternak ayam Barokah rutin mengunggah foto untuk memberikan informasi pada viewers tentang ayam Barokah. Pemasaran interaktif oleh Usaha ternak ayam Barokah melalui media Facebook, Instagram, dan Website sangat mendukung strategi digital marketing dalam meningkatkan penjualan.

Ayam Barokah selalu berusaha memposting produk-produknya dengan menarik. Menu pada Facebook dan Instagram diberikan fasilitas bagi konsumen untuk memberikan komentar dan respon seputar pengalamannya dengan produk-produk ayam Barokah. Pengunjung dapat memberikan komentar secara langsung di bawah materi postingan, sehingga pengunjung yang lain dapat mengolah informasi tersebut untuk mempertimbangkan melalukan pembelian.

Tabel 3.

Hasil Analisis Tanggapan Konsumen

\begin{tabular}{|c|c|c|c|c|c|}
\hline aan & \multicolumn{5}{|c|}{ Alternatif Jawaban (N/\%) } \\
\hline $\begin{array}{l}\text { Alasan utama } \\
\text { membeli } \\
\text { daging ayam }\end{array}$ & \begin{tabular}{|c|} 
Lebih \\
uurah da \\
enak \\
46 \\
$(57,5 \%)$
\end{tabular} & \begin{tabular}{|c|} 
Variasi \\
menu \\
nakanar \\
23 \\
$(28,8 \%)$ \\
\end{tabular} & \begin{tabular}{|c|}
$\begin{array}{c}\text { Lebih } \\
\text { mudah } \\
\text { niperolel } \\
(12,5 \%\end{array}$ \\
\end{tabular} & $\begin{array}{c}\text { Lebih } \\
\text { bergizi } \\
1 \\
(1,3 \%)\end{array}$ & - \\
\hline $\begin{array}{l}\text { Keputusan } \\
\text { pembelian } \\
\text { daging ayam }\end{array}$ & $\begin{array}{c}\text { erencan } \\
\text { erjadwa } \\
15 \\
(18,8 \%)\end{array}$ & $\begin{array}{c}58 \\
(72,5 \%)\end{array}$ & $\begin{array}{c}6 \\
(7,5 \%)\end{array}$ & $\begin{array}{c}1 \\
(1,3 \%)\end{array}$ & $\begin{array}{c}\text { ainnya.. } \\
\text {.. } \\
-\end{array}$ \\
\hline $\begin{array}{l}\text { Jumlah pem- } \\
\text { belian daging } \\
\text { ayam/transaksi }\end{array}$ & $\mathrm{g} \mid \begin{array}{c}2 \mathrm{~kg} \\
39 \\
(48,8 \%)\end{array}$ & $\begin{array}{c}27 \\
(33,8 \%) \\
\end{array}$ & $\begin{array}{c}7 \\
(8,8 \%)\end{array}$ & $\begin{array}{c}0 \text { gram. } \\
1 \mathrm{Kg} \\
7 \\
(8,8 \%)\end{array}$ & $500 \xi$ \\
\hline $\begin{array}{l}\text { Lokasi } \\
\text { pembelian } \\
\text { daging ayam } \\
\text { biasanya }\end{array}$ & $\begin{array}{l}\text { Peternak } \\
\text { angsuns }\end{array}$ & $\begin{array}{c}32 \\
(40,0 \%)\end{array}$ & $\begin{array}{l}\text { edagan: } \\
\text { keliling }\end{array}$ & $\begin{array}{l}\text { Media } \\
\text { online }\end{array}$ & nya \\
\hline $\begin{array}{l}\text { Pertimbangan } \\
\text { pemilihan } \\
\text { tempat } \\
\text { pembelian }\end{array}$ & $\begin{array}{l}\text { Harga } \\
\text { murah }\end{array}$ & ters & $\begin{array}{c}38 \\
(47,5 \%)\end{array}$ & - & nya \\
\hline $\begin{array}{l}\text { Pengalaman } \\
\text { membeli } \\
\text { daging ayam } \\
\text { online }\end{array}$ & $\begin{array}{r}32 \\
(40,0 \% \\
\end{array}$ & Sering & Pernah & $\begin{array}{l}\text { Kadang } \\
\text { kadang }\end{array}$ & $n$ \\
\hline $\begin{array}{l}\text { Alasan } \\
\text { membeli } \\
\text { daging ayam } \\
\text { online }\end{array}$ & $\begin{array}{c}\text { ludah dq } \\
\text { cepat }\end{array}$ & $\begin{array}{c}\text { arga leb } \\
\text { pasti }\end{array}$ & $\begin{array}{l}\text { Mudah } \\
\text { hengece }\end{array}$ & $\begin{array}{c}\text { Lebih } \\
\text { simpel }\end{array}$ & $\begin{array}{c}\text { ainnya.. } \\
. .\end{array}$ \\
\hline
\end{tabular}




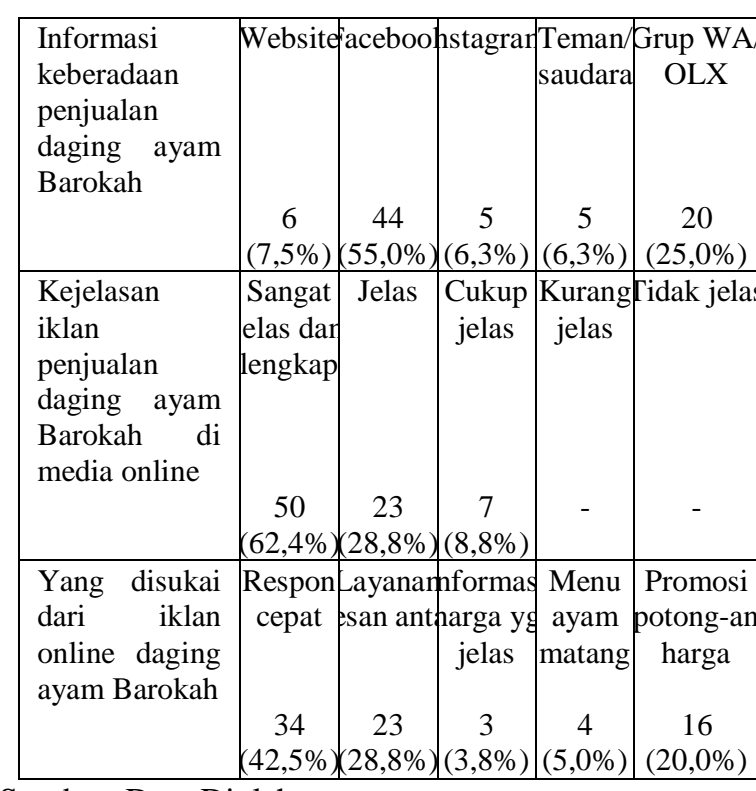

Sumber: Data Diolah

Dapat diketahui bahwa alasan utama konsumen membeli daging ayam sebagian besar adalah karena lebih murah dan enak $(57,5 \%)$. Kemudian keputusan pembelian daging ayam dilakukan adalah tergantung kebutuhan (72,5\%). Jumlah pembelian daging ayam setiap transaksi sebagian besar adalah lebih dari $2 \mathrm{~kg}(48,8 \%)$. Adapun lokasi tempat pembelian daging ayam yang biasanya dituju konsumen adalah di pasar $(40,0 \%)$ dan media online $(33,8 \%)$. Pertimbangan yang dipilih konsumen saat pemilihan tempat pembelian adalah karena harga yang murah $(36,2 \%)$ dan mudah dijangkau $(47,5 \%)$.

Ditinjau dari pengalaman konsumen membeli daging ayam secara online sebagian besar konsumen menjawab selalu membeli secara online $(40,0 \%)$ dan sering $(42,5 \%)$. Alasan membeli daging ayam secara online adalah karena mudah dan cepat $(28,8 \%)$ serta lebih simpel $(55,0 \%)$. Konsumen memperoleh informasi tentang keberadaan penjualan daging ayam Barokah sebagian besar dari Facebook $(55,0 \%)$ selanjurnya dari Grup WA/ OLX (25,0\%). Tanggapan konsumen tentang kejelasan iklan penjualan daging ayam Barokah di media online adalah sudah sangat jelas dan lengkap $(62,4 \%)$. Adapun hal yang paling disukai dari iklan online daging ayam Barokah adalah karena respon yang cepat (42,5\%), adanya layanan pesan antar $(28,8 \%)$, dan adanya promosi potongan harga $(20,0 \%)$.

Tanggapan konsumen tersebut menunjukkan bahwa pemasaran digital saat ini memang strategi pemasaran yang dibutuhkan untuk berinteraksi dengan konsumen melalui media online. Pemasaran digital (misalnya melalui Facebook yang lagi trend saat ini), tentunya memberikan manfaat positif baik bagi perusahaan maupun konsumen. Perusahaan dapat menampilkan iklan produk ataupun jasa yang dipromosikan. Perusahaan dapat menghasilkan penjualan yang tinggi karena dapat menjangkau konsumen lebih luas melalui internet. Perusahaan juga menawarkan mekanisme respon cepat terhadap kebutuhan konsumen secara maksimal. Oleh karena itu, adanya respon yang cepat sangat diperlukan dalam perusahaan terutama bagian pemasaran digital. Konsumen mengharapkan adanya pelayanan pelanggan yang cepat tanggap dalam memberikan informasi dan memberikan pelayanan yang maksimal secara online memlalui sosial media.

Digital marketing melalui media sosial lebih menguntungkan karena media sosial memungkinkan pengguna membuat suatu halaman untuk mewakili suatu produk, organisasi atau perusahaan dalam melakukan hubungan (komunikasi, promosi, dan lain-lain) dengan pengguna media sosial lain yang menyukai halaman yang telah dibuat tersebut. Halaman Facebook misalnya bisa menjadi salah satu alternatif media promosi dan ayam Barokah memanfaatkan peluang ini untuk mempromosikan produk ayamnya.

Media jejaring sosial dirasakan relatif lebih murah dan lebih mudah untuk diakses untuk siapa saja untuk menyampaikan serta mendapat informasi, dibanding dengan media tradisional (koran, radio, televisi) yang memerlukan biaya yang lebih mahal serta sulit untuk menyampaikan informasi. Promosi melalui media sosial memberikan kemudahan bagi konsumen untuk bertransaksi secara online. Facebook memungkinkan bagi penggunanya untuk dapat memberikan dan mengkonsumsi informasi, serta memberikan kesempatan bagi konsumen online dapat memberikan komentarnya ataupun mengirim pesan untuk pemilik produk yang dipromosikan.

Berbagai keuntungan dari penggunaan strategi ini antara lain promosi yang lebih cepat dan jangkauan lebih luas. Jika selama ini produk ayam hanya dipasarkan melalui distributor, maka melalui strategi digital marketing calon konsumen bisa datang dari kalangan mana saja. Media sosial menjadi salah satu media promosi yang mudah diakses dan mudah dimengerti. Apalagi sekarang hampir semua orang mempunyai Facebook ataupun Instagram, dan bagi yang belum bergabung dalam bisa dengan mudah ikut bergabung yaitu dengan membuat email dan password sebagai kata kunci untuk membukanya. Di media sosial seseorang bisa mempromosikan suatu produk juga lebih mudah, tinggal memasang gambar atau foto dari produk yang akan dipasarkan dengan diberi beragam uraian penjelasan seperti harga yang ditawarkan, kemudian gambar atau foto tersebut di tag atau dikirim ke semua teman-teman dalam komunitasnya. Dengan begitu iklan tersebut langsung dapat diterima oleh semua teman dalam komunitas tadi. Artinya informasi dapat tersebar dengan lebih cepat dan daya jangkau yang luas. 


\section{KESIMPULAN}

Berdasarkan hasil penelitian dan pembahasan yang telah diuraikan maka diambil kesimpulan sebagai berikut:

Pengembangan strategi digital marketing adalah strategi yang dilakukan oleh ternak ayam Barokah di Teras Boyolali untuk mengantisipasi menurunnya penjualan ayam secara konvensional di masa Pandemi Covid 19. Melalui strategi digital marketing ayam Barokah mempromosikan atau memberikan informasi kepada masyarakat secara online dengan menggunakan berbagai media online baik melalui website maupun media sosial Facebook maupun Instagram. Pengembangan strategi digital marketing ini dilaksanakan melalui tahap segmentasi, targeting, dan positioning. Kemudian dilanjutkan dengan mengkombinasikan 3 unsur bauran pemasaran berupa harga, produk, dan tempat untuk mendukung unsur kempat yaitu promosi sebagai inti dari strategi digital marketing. Pengembangan strategi digital marketing ayam Barokah dilakukan melalui periklanan online yang berisi informasi mengenai variasi produk, harga dan cara pemesanan, penjualan langsung maupun layanan pesan antar, penjualan pribadi dan presentasi, serta melayani tanya jawab dengan konsumen di media online (pemasaran interaktif).

\section{REFERENSI}

Aprilia, L. Cryrilla, L. \& burhanuddin. (2018). Analisis Strategi Pemasaran Ternak Berbasis E-Commerce. Jurnal Ilmu Produksi Dan Teknologi Hasil Peternakan, 06.

Barus. (2016). Peran internet dalam saluran Distribusi UMKM. Jurnal Administrasi Bisnis Unpar, 12.

Coviello, N., Milley, R., \& Marcolin, B. (2001). Understanding IT-enabled interactivity in contemporary marketing. Journal of Interactive
Marketing, 15(4), 18-33. https://doi.org/10.1002/dir.1020

Kotler, P., \& Armstrong, G. (2012). Prinsip-Prinsip Pemasaran (13th ed.).

Miles, M.B, Huberman, A.M, dan Saldana, J. (2014). Qualitative Data Analysis, A Methods Sourcebook (edisi 3).

Morissan, A. . (2014). Periklanan Komunikasi Pemasaran Terpadu. Kencana Prenadamedia Group.

Nadya. (2016). Peran Digital Marketing Dalam Eksistensi Bisnis Kuliner Seblak Jeletet Murni. Jurnal Riset Manajemen Dan Bisnis (JRMB).

Purwana, Dedi, Es, R. dan S. A. (2017). Pemanfaatan Digital Marketing Bagi Usaha Mikro, Kecil, Dan Menengah (UMKM) Dikelurahan Malaka Sari Duren Sawit. Jurnal Pemberdayaan Masyarakat Madani (JPMM), 1.

Sanjaya, R., \& Tarigan, J. (2009). Creative Digital Marketing. PT Elex Media Komputindo.

Sugiyono. (2016). Metode Penelitian Kuantitatif, Kualitatif, dan R\&D. PT Alfabet.

Yusuf, O. (2014). Pengguna Internet Indonesia Nomor Enam Dunia. Kompas. https://tekno.kompas.com/read/2014/11/24/07 430087/Pengguna.Internet.Indonesia.Nomor.E nam.Dunia 